\title{
FIVE NEW SPECIES OF CAUCAEA (ORCHIDACEAE) FROM COLOMBIA AND ECUADOR
}

\author{
Dariusz L. SzlachetKo \& Marta KolanowsKa ${ }^{1}$
}

\begin{abstract}
Five new species of Caucaea Schltr. (C. caucana Szlach. \& Kolan., C. pichinchae Szlach. \& Kolan., C. dodsoniana Szlach. \& Kolan., C. pseudoandigena Szlach. \& Kolan., C. duquei Szlach. \& Kolan.) are described and illustrated. The taxonomic affinities of the new entities are discussed, and information about their habitat and ecology is provided. A key for identification of Caucaea species known from Colombia and Ecuador is provided.
\end{abstract}

Key words: biodiversity, Caucaea, distribution, Neotropics, Oncidiinae, taxonomy

Dariusz L. Szlachetko \& Marta Kolanowska, Department of Plant Taxonomy and Nature Conservation, University of Gdańsk, Wita Stwosza 59,80-308 Gdańsk, Poland; e-mail: martakolanowska@wp.pl

\section{INTRODUCTION}

The systematics of the orchid genus Oncidium Sw. and its relatives has been discussed for over 170 years. More than 1100 specific epithets have been applied to this taxon since its description by Swartz (1800). The great phenotypic variation observed within oncidioid orchids and the superficial uniformity of their floral morphology have provoked lively discussion of the taxonomy of Oncidium and the need to delimit smaller, morphologically clearly defined taxa. Preliminary studies on infrageneric classification were made by Lindley (Lindley \& Paxton 1850-1851; Lindley 1855), who recognized 14 sections within Oncidium, but the first comprehensive infrageneric classification of the genus was proposed by Kraenzlin (1922), who recognized 18 sections within the genus. Some of them were later elevated to generic rank: for example, Oncidium sect. Heterantha Kraenzl. to Heteranthocidium Szlach., Mytnik \& Romowicz, or Oncidium sect. Teretifolia Lindl. to Cohniella Pfitzer. One of Kraenzlin's sections whose taxonomic status has been recently studied is Oncidium sect. Cucullata Kraenzl., typified by O. cucullatum Lindl., distinguished according to Kraenzlin by the coriaceous

\footnotetext{
1 Corresponding author
}

leaves, partially connate lateral sepals, tepals being smaller than the lip, and entire lip isthmus margin. A revision of this group was published by Stacy (1975), who also suggested its distinctiveness from Oncidium s.str. Molecular studies (Williams et al. 2001) revealed the close relation of the section's representatives with the genus Caucaea Schltr., which for a long time was recognized as a monospecific taxon containing only $C$. radiata (Lindl.) Mansf.; the authors proposed synonymization of the two genera under the name Caucaea, but this concept was rejected by Dodson and Luer (2005). Studies of gynostemium morphology (Szlachetko \& Mytnik-Ejsmont 2009) confirmed the similarity in construction of the reproductive structures between $C$. radiata and representatives of Oncidium sect. Cucullata. Subsequent genetic analysis of Oncidiinae by Neubig et al. (2012) confirmed the phylogenetic distance of Caucaea (sensu Williams et al. 2001) from Oncidium. Those studies indicated the close relation of the genus with taxa of the Cyrtochilum complex [Siederella Szlach., Mytnik, Górniak \& Romowicz, Cyrtochilum loxense (Lindl.) Kraenzl.] and Miltoniopsis God.-Leb.

As currently recognized, Caucaea includes species characterized by ovoid to cylindric-ovoid 
pseudobulbs enclothed basally with 1-3 foliaceous bracts and (1)2 conduplicate leaves at the top. Their resupinate flowers are arranged into often fractiflex, 1- to many-flowered inflorescences. The floral bracts are shorter than the pedicels and the ovaries. The lateral sepals are partially to completely fused and both the dorsal sepal and petals are free. The lip is panduriform or deeply 3-lobed, with a basal callus consisting most often of 2-3 ridges. The gynostemium is slightly arched and rather stout, with the column part 2-3 times as long as the anther, winged and enlarged at the base. No column foot is observed. The subapical to ventral anther is incumbent, operculate, ellipsoid, obscurely 2-chambered. Two obliquely obovoid, slightly dorsiventrally compressed, hard, apically unequally cleft pollinia are produced. The apical clinandrium forms a narrow collar surrounding the anther base. The rather large stigma is transversely elliptic to elliptic, and deeply concave. The rostellum is suberect, ligulate, and its remnant is centrally bilobulate, slightly concave between the acute lobules, and canaliculate on the dorsal surface.

Plants of Caucaea are usually found growing as epiphytes in cool, wet montane forest or highmontane Andean cloud forest, most often above $2500 \mathrm{~m}$ a.s.1. Caucaea contains ca 20 species distributed from Colombia and Venezuela south to Peru, with the greatest diversity observed in Ecuador.

Recent studies of Oncidiinae revealed the existence of five distinctive species, three from Ecuador and two from Colombia, which are described here as new and placed within a key for identification of Caucaea reported from both countries. Previously seven species of the genus were found in Colombia (Ortiz Valdivieso \& Uribe Vélez 2007) and 16 in Ecuador (Stacy 1975; Königer 2003).

\section{TAXONOMIC TREATMENT}

Caucaea caucana Szlach. \& Kolan., sp. nov.

Fig. 1

Species similar to C. cucullata (Lindl.) N. H. Williams \& M. W. Chase, but with smaller flowers, suborbicular-ovate petals, an inconspicuous lip isthmus, shortly bifid lip middle lobe and glabrous lip callus.

Holotype: COLOMBIA. Cauca: Macizo Colombiano; páramo de Las papas, entre El Bosquerón y La Hoyola. Camino San Agustin-Valencia, Alt. 3200-3510 m, 7-27 Sep. 1958, Idrobo, Pinto \& Bischler 3036 (MO).

Pseudobulb $5.5 \mathrm{~cm}$ long, $2 \mathrm{~cm}$ wide, ovoid, bilaterally compressed, bifoliate, subtended by foliaceous sheaths. Leaves up to $13 \mathrm{~cm}$ long, $3 \mathrm{~cm}$ wide, ligulate, lanceolate to elliptic-lanceolate, obtuse. Inflorescence $40 \mathrm{~cm}$ long, paniculate, several-flowered. Tepals green with rose spots, lip lilac with violet spots. Floral bract $c a 3 \mathrm{~mm}$ long, triangular-ovate, acute. Pedicel and ovary $23 \mathrm{~mm}$ long. Dorsal sepal $14 \mathrm{~mm}$ long, $5 \mathrm{~mm}$ wide, thick, oblong-elliptic, obtuse, 5-veined. Petals $12 \mathrm{~mm}$ long, $7 \mathrm{~mm}$ wide, ovate-suborbicular

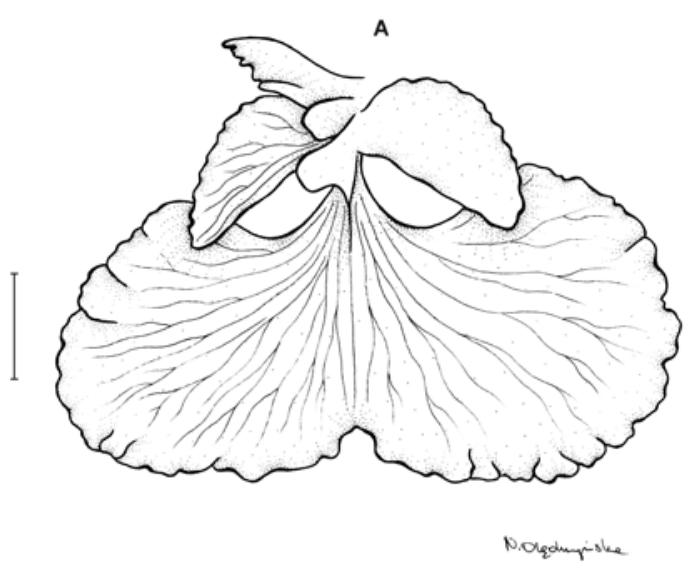

D
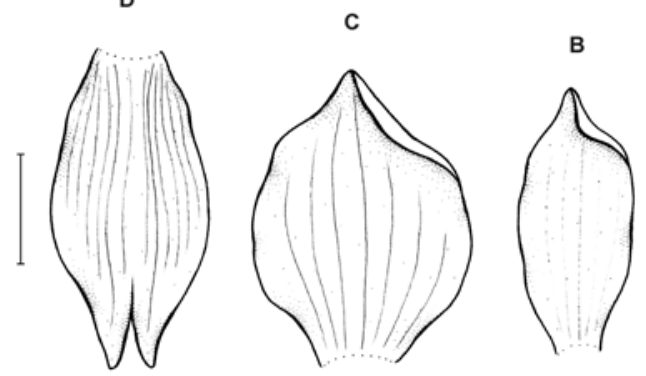

Fig. 1. Caucaea caucana Szlach. \& Kolan., sp. nov. - dissected perianth. A - lip and gynostemium, B - dorsal sepal, $\mathrm{C}$ - petal, D - lateral sepals. Scale bars $=5 \mathrm{~mm}$. Drawn by N. Olędrzyńska from the holotype. 


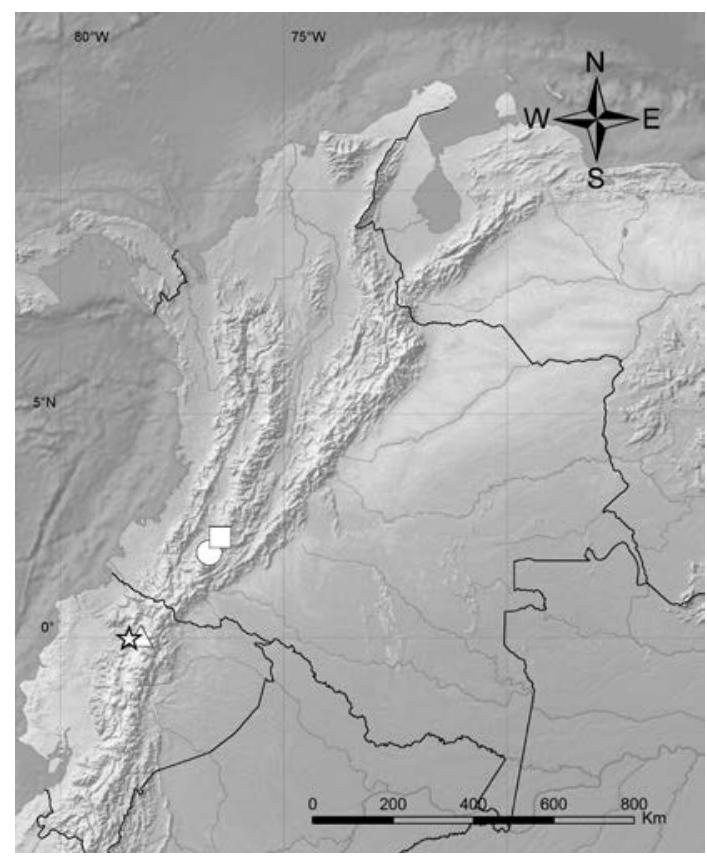

Fig. 2. Distribution of new Caucaea Schltr. species: C. caucana Szlach. \& Kolan. (○), C. pichinchae Szlach. \& Kolan. $(\triangle)$, C. dodsoniana Szlach. \& Kolan. (स) and C. duquei Szlach. \& Kolan. ( $\square)$.

above a narrow base, obtuse, 7-veined, somewhat oblique. Lateral sepals $15 \mathrm{~mm}$ long, together $7 \mathrm{~mm}$ wide, connate for $\mathrm{ca} 3 / 4$ of their length, free apices subobtuse, each sepal 6-veined. Lip $20 \mathrm{~mm}$ long, $23 \mathrm{~mm}$ wide, fleshy, deeply 3-lobed; lateral lobes $9 \mathrm{~mm}$ long, $6 \mathrm{~mm}$ wide, dolabriform, margins crenulate, apex obtuse; isthmus inconspicuous; middle lobe $15 \mathrm{~mm}$ long, transversely ellipticreniform, subcordate at base, apex shortly bifid, margins undulate; callus a short, obtuse ridge. Gynostemium $7 \mathrm{~mm}$ long, somewhat sigmoid, clinandrium slightly dentate.

ETYMOLOGY. In reference to the place of origin of the type specimen.

HABITAT, ECOLOGY AND DISTRIBUTION. Known only from the Colombian Andes (Fig. 2). Growing epiphytically at 3000-3510 $\mathrm{m}$ a.s.l. Flowering in September.

Notes. This species resembles $C$. cucullata (Lindl.) N. H. Williams \& M. W. Chase but its flowers are smaller (dorsal sepal 14 vs $20 \mathrm{~mm}$ long, petals 12 vs $19 \mathrm{~mm}$ long), the petals are suborbicular-ovate above a narrow base (vs petals ovate-lanceolate), the lip isthmus is inconspicuous (vs prominent), the lip middle lobe is shortly bifid (vs deeply bifid) and the lip callus is glabrous (vs hairy at base). Unlike in C. olivacea (Kunth) N. H. Williams \& M. W. Chase, the lip callus of the new species constitutes $c a 1 / 5$ of the lip length (vs $1 / 3$ of lip length), it is not hairy in the basal part, the lip middle lobe is not deeply bifid nor deeply cordate at the base, and the lip isthmus is inconspicuous.

Caucaea pichinchae Szlach. \& Kolan., sp. nov.

Fig. 3

Species similar to C. cucullata (Lindl.) N. H. Williams \& M. W. Chase but with an ovate-elliptic, obtuse dorsal sepal, and glabrous callus in the form of two parallel ridges.

Holotype: ECUADOR. Pichincha: Tabacundo. Quebrada Chimburlo, km 47. Canal de riego principal.

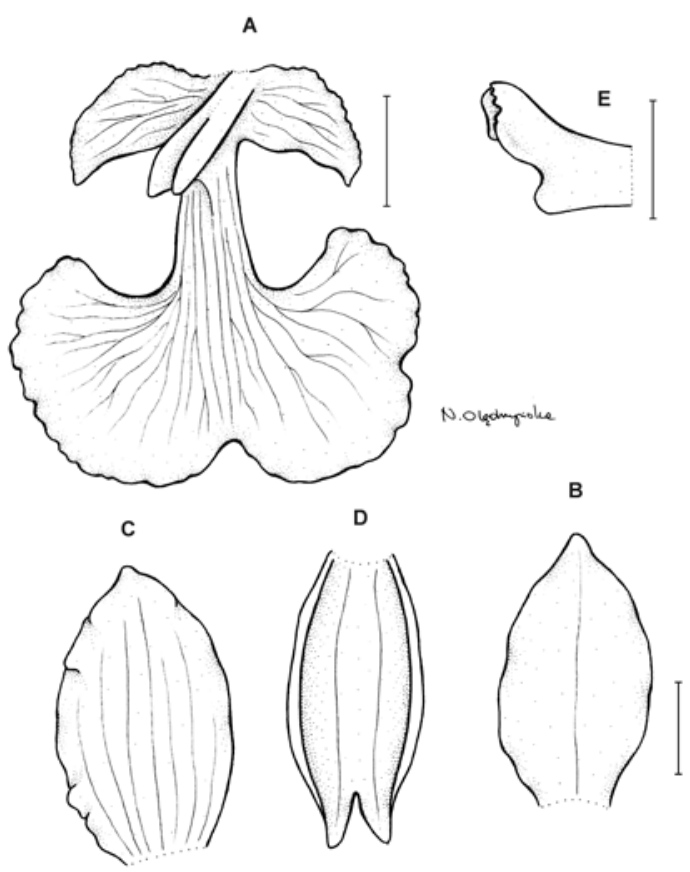

Fig. 3. Caucaea pichinchae Szlach. \& Kolan., sp. nov. - dissected perianth. A - lip, B - dorsal sepal, C - petal, D - lateral sepals, $\mathrm{E}-$ gynostemium. Scale bars $=5 \mathrm{~mm}$. Drawn by N. Olędrzyńska from the holotype. 
$00^{\circ} 07^{\prime} \mathrm{N} 78^{\circ} 08^{\prime} \mathrm{W}$, Alt. $3000 \mathrm{~m}, 12$ Aug., Cuamacás \& Gudiño $667(\mathrm{MO})$.

Pseudobulb $7 \mathrm{~cm}$ long, $1.8 \mathrm{~cm}$ wide, cylindrical-ovoid, bilaterally compressed, bifoliate. Leaves up to $42 \mathrm{~cm}$ long, $2.7 \mathrm{~cm}$ wide, linearlanceolate, subobtuse. Inflorescence $c a 100 \mathrm{~cm}$ long, racemose, branching, laxly several-flowered. Flowers rose-colored with purple spots. Floral bract $3 \mathrm{~mm}$ long, ovate-triangular, acute. Pedicel and ovary $27 \mathrm{~mm}$ long. Dorsal sepal $15 \mathrm{~mm}$ long, $6.5 \mathrm{~mm}$ wide, ovate-elliptic, obtuse, 1-veined. Petals $15 \mathrm{~mm}$ long, $8 \mathrm{~mm}$ wide, thick, elliptic, obtuse, somewhat oblique, margins minutely undulate, 7-veined. Lateral sepals $15 \mathrm{~mm}$ long, $7.5 \mathrm{~mm}$ wide together, connate almost to the obtuse apices, synsepal concave. Lip ca $20 \mathrm{~mm}$ long, $17 \mathrm{~mm}$ wide across lateral lobes, $20 \mathrm{~mm}$ wide across middle lobe, rather thin, deeply 3-lobed; lateral lobes ca $3.5 \mathrm{~mm}$ wide, dolabriform, margins minutely crenate, apex subacute; isthmus prominent, ca $7 \mathrm{~mm}$ long, narrow; middle lobe $12 \mathrm{~mm}$ long, cordate at base, flabellate, shortly bifid, margins undulate; callus consisting of two parallel keel-like ridges which extend to $c a$ 1/3 of lip length. Gynostemium $7 \mathrm{~mm}$ long, apically bent back, clinandrium somewhat dentate.

ETYMOLOGY. In reference to the place of origin of the type specimen.

Habitat, ECOLOGY AND DistribUtion. Known only from Ecuador (Fig. 2). Growing at $c a$ $3000 \mathrm{~m}$ a.s.l. Flowering in August.

Notes. This species resembles $C$. cucullata (Lindl.) N. H. Williams \& M. W. Chase, from which it differs by the ovate-elliptic, obtuse dorsal sepal (vs oblong-lanceolate, acute), and glabrous callus (vs hairy at base) in the form of two parallel ridges (vs one or three keel-like ridge(s)).

Caucaea dodsoniana Szlach. \& Kolan., sp. nov.

Fig. 4

Species similar to C. olivacea (Kunth) N. H. Williams \& M. W. Chase and C. cucullata (Lindl.) N. H. Williams \& M. W. Chase, but with a glabrous callus, obliquely ovate-dolabriform lip lateral lobes and relatively broad lip isthmus.
HolotyPe: ECUADOR. Pichincha: Quito. Reserva Geobotánica del Pululahua. Sendero El Hospital-Manca Quito. $00^{\circ} 05^{\prime} \mathrm{N}, 78^{\circ} 30^{\prime} \mathrm{W}$, Alt. $3100-3200 \mathrm{~m}, 7$ Feb. 1992, Cerón \& Reyna 18184 (MO).

Pseudobulb $6 \mathrm{~cm}$ long, $2.3 \mathrm{~cm}$ wide, ovoid, bilaterally compressed, bifoliate. Leaves up to $40 \mathrm{~cm}$ long, $3 \mathrm{~cm}$ wide, lanceolate, acute. Inflorescence $c a$ $95 \mathrm{~cm}$ long, paniculate, sublaxly many-flowered. Flowers lilac with darker spots. Floral bract $4 \mathrm{~mm}$ long, triangular-ovate, acute. Pedicel and ovary $25 \mathrm{~mm}$ long. Dorsal sepal $14 \mathrm{~mm}$ long, $6.8 \mathrm{~mm}$ wide, elliptic, obtuse, 9-veined, apex recurved. Petals $13 \mathrm{~mm}$ long, $9 \mathrm{~mm}$ wide, obliquely broadly ovate, subobtuse, 9-veined, apex recurved. Lateral sepals $15 \mathrm{~mm}$ long, together $8 \mathrm{~mm}$ wide, connate almost to the subacute, diverging apices, elliptic in general outline. Lip ca $20 \mathrm{~mm}$ long, $14 \mathrm{~mm}$ wide across lateral lobes, $23 \mathrm{~mm}$ wide across middle
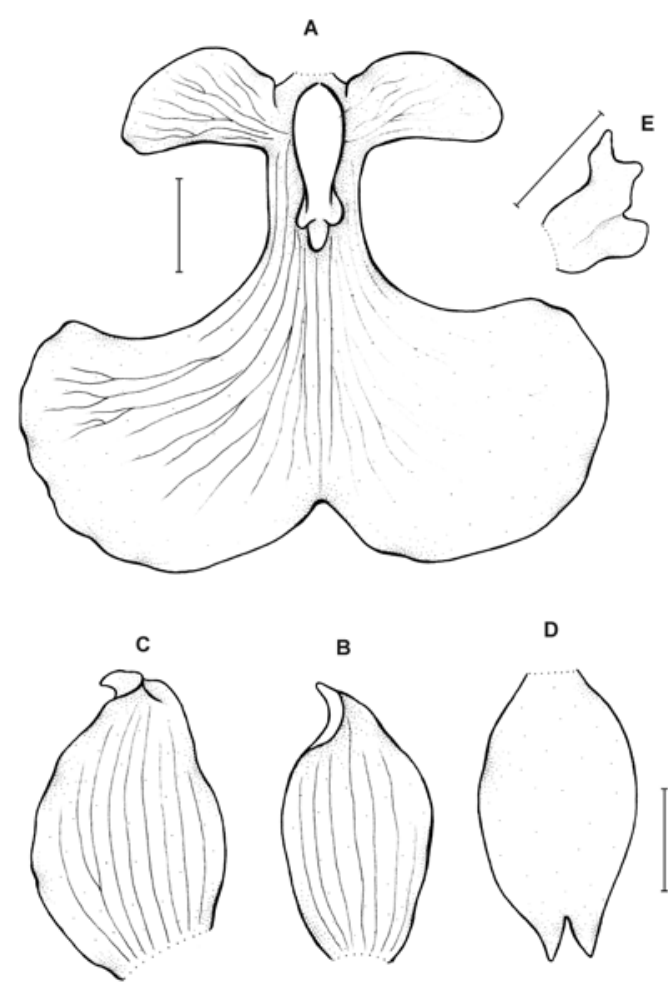

Fig. 4. Caucaea dodsoniana Szlach. \& Kolan., sp. nov. - dissected perianth. A - lip, B - dorsal sepal, C - petal, D - lateral sepals, $\mathrm{E}-$ gynostemium. Scale bars $=5 \mathrm{~mm}$. Drawn by N. Olędrzyńska from the holotype. 
lobe, deeply 3-lobed; lateral lobes $5 \mathrm{~mm}$ wide, obliquely ovate-dolabriform, rounded; isthmus $4.3 \mathrm{~mm}$ long, $3.5 \mathrm{~mm}$ wide; middle lobe $\mathrm{ca} 10 \mathrm{~mm}$ long, cuneate-flabellate, shortly bifid at apex, margins slightly undulate; callus an ovate pad with a pair of small, rounded appendices in apical part. Gynostemium $5 \mathrm{~mm}$ long, robust, apical part bent back, clinandrium entire.

Eтymology. Dedicated to Calaway H. Dodson, eminent American orchidologist.

HABITAT, ECOLOGY AND DISTRIBUTION. Known only from Ecuador (Fig. 2). Growing epiphytically at $c a$ 3100-3200 m a.s.l. Flowering in February.

Notes. In the form of the lip callus this species resembles $C$. olivacea (Kunth) N. H. Williams $\&$ M. W. Chase, but the callus of the new species is glabrous (vs hairy in basal part) and its lip lateral lobes are obliquely ovate-dolabriform (vs obliquely ovate), the lip isthmus is relatively broad (vs narrow), and the lip middle lobe base is cuneate (vs deeply cordate). In C. cucullata (Lindl.) N. H. Williams \& M. W. Chase the lip lateral lobes are subquadrate and the middle lobe is deeply cordate at the base. The callus of this species consists of three keel-like ridges.

Caucaea pseudoandigena Szlach. \& Kolan., sp. nov.

Fig. 5

Species similar to $C$. andigena (Linden \& Rchb. f.) N. H. Williams \& M. W. Chase, but with an oblong-elliptic dorsal sepal, shortly connate lateral sepals, ovate-subrectangular petals, a larger lip and a deeply bifid, basally cordate lip middle lobe.

Holotype: [ECUADOR]. Cultivated in Loja, 15 Oct. 1982, Heiser s.n. (MO).

Pseudobulb $4.5 \mathrm{~cm}$ long, $0.8 \mathrm{~cm}$ wide, cylindrical, bilaterally compressed, bifoliate. Leaves up to $14 \mathrm{~cm}$ long, $1 \mathrm{~cm}$ wide, linear-lanceolate, attenuate towards obtuse apex. Inflorescence $35 \mathrm{~cm}$ long, racemose, laxly few-flowered. Floral bract ca $2 \mathrm{~mm}$ long, obscure. Pedicel and ovary $13 \mathrm{~mm}$ long. Dorsal sepal $8.5 \mathrm{~mm}$ long, $5 \mathrm{~mm}$ wide, oblong-elliptic, apiculate, obtuse, 7-veined. Petals $8.5 \mathrm{~mm}$ long, $5.5 \mathrm{~mm}$ wide, ovate-subrectangular, apiculate, primarily 5-veined. Lateral

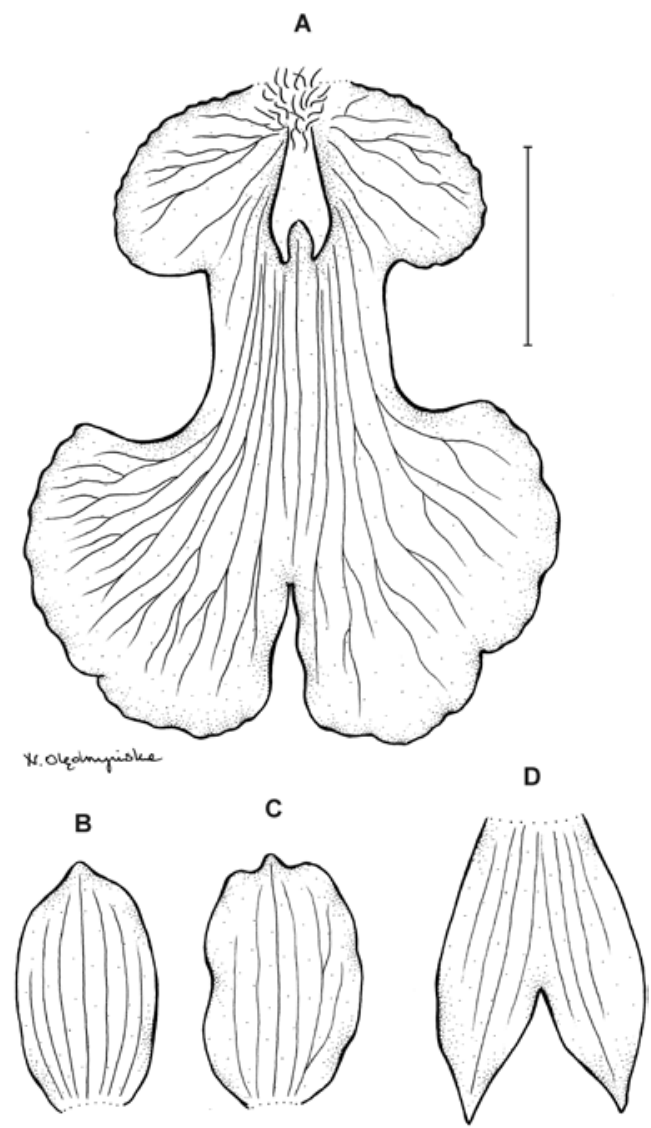

Fig. 5. Caucaea pseudoandigena Szlach. \& Kolan., sp. nov. - dissected perianth. A - lip, B - dorsal sepal, C - petal, D lateral sepals. Scale bars $=5 \mathrm{~mm}$. Drawn by N. Olędrzyńska from the holotype.

sepals $11 \mathrm{~mm}$ long, $2.8 \mathrm{~mm}$ wide, connate to about the middle, free apices acute, diverging, each sepal 4-veined. Lip ca $16 \mathrm{~mm}$ long, $16 \mathrm{~mm}$ wide across middle lobe, $8 \mathrm{~mm}$ wide across lateral lobes, deeply 3-lobed, lateral lobes $4.5 \mathrm{~mm}$ long, obliquely broadly ovate, rounded, margin somewhat crenulate; isthmus prominent, ca $3.5 \mathrm{~mm}$ long, $4.5 \mathrm{~mm}$ wide; middle lobe $9.5 \mathrm{~mm}$ long, deeply bifid, reniform in outline, margins undulate; callus pliers-shaped, hairy at base.

ETYMology. In reference to the similarity to C. andigena.

Habitat, ECOlOGY AND Distribution. Place of collection not stated, probably Ecuador. Epiphytic 
plant, habitat unknown. In cultivation, flowering in October.

Notes. This species resembles $C$. andigena (Linden \& Rchb. f.) N. H. Williams \& M. W. Chase but it is easily distinguished from this species by the tepals and lip form. Unlike in C. andigena, the lateral sepals are connate to about the middle (vs free only at apices), the dorsal sepal is oblong-elliptic (vs elliptic-oblong) and the petals are ovate-subrectangular (vs elliptic-oblong). The lip of the new species is about twice longer than the tepals (vs lip slightly longer than tepals in $C$. andigena) and the lip middle lobe is deeply bifid and cordate at the base (vs shortly bifid, truncate at base).

Caucaea duquei Szlach. \& Kolan., sp. nov.

Fig. 6

Species similar to C. olivacea (Kunth) N. H. Williams \& M. W. Chase but with a short, cup-like lip callus and lateral sepals connate to $c a 2 / 3$ of their length.

Holotype: COLOMBIA. Cauca: Zona sur del Parque Nacional de Puracé, Macizo Colombiano, margen izquierdo Río Caqueta, camino a la laguna "Santiago", sector Valencia, Alt. 3200 m, 21 Sep. 1967, Duque 620 (COL).

Pseudobulb $7 \mathrm{~cm}$ long, $1 \mathrm{~cm}$ wide, ovoid-cylindric, bilaterally compressed, bifoliate. Leaves up to $30 \mathrm{~cm}$ long and $2 \mathrm{~cm}$ wide, narrowly lanceolate, acute. Inflorescence over $120 \mathrm{~cm}$ long, racemose, rather laxly many-flowered. Floral bract $4 \mathrm{~mm}$ long, ovate, subobtuse. Pedicel $22 \mathrm{~mm}$ long, ovary $10 \mathrm{~mm}$ long. Tepals very thick, stiff, greyish-green, lip violet-purple. Dorsal sepal $16 \mathrm{~mm}$ long, $7 \mathrm{~mm}$ wide, concave, oblong ovate, obtuse, apex slightly recurved. Petals $14 \mathrm{~mm}$ long, $8 \mathrm{~mm}$ wide, concave in central part, ovateelliptic, acuminate. Lateral sepals $18 \mathrm{~mm}$ long, $4 \mathrm{~mm}$ wide, connate to $c a 2 / 3$ of their length, free apices obtuse, somewhat diverging, each sepal 6-veined. Lip ca $28 \mathrm{~mm}$ long, $30 \mathrm{~mm}$ wide across middle lobe, deeply 3-lobed above base; lateral lobes $9 \mathrm{~mm}$ long, dolabriform, margins undulate, apex rounded; isthmus short, ca $5 \mathrm{~mm}$ long, narrow; middle lobe $18 \mathrm{~mm}$ long, reniform,

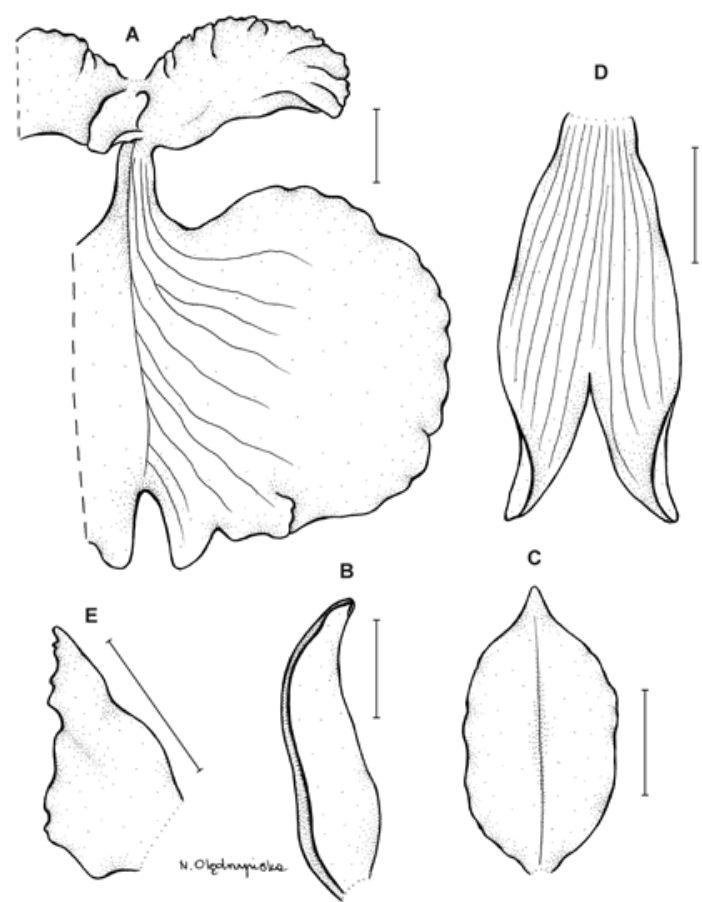

Fig. 6. Caucaea duquei Szlach. \& Kolan., sp. nov. - dissected perianth. A - lip, B - dorsal sepal, C - petal, D - lateral sepals, $\mathrm{E}-$ gynostemium. Scale bars $=5 \mathrm{~mm}$. Drawn by N. Olędrzyńska from the holotype.

shortly bifid, margins undulate; callus in form of concave, cup-like thickening in basal 1/7 of lip. Gynostemium $8.5 \mathrm{~mm}$ long, erect, rather robust, clinnadrium narrow, almost entire.

Etymology. Dedicated to Andrés Duque, collector of the type specimen.

HABITAT, ECOLOGY AND DISTRIBUTION. Known so far only from the Colombian Andes (Fig. 2). Growing epiphytically at ca $3200 \mathrm{~m}$ a.s.l. Flowering in September.

Notes. This species resembles $C$. olivacea (Kunth) N. H. Williams \& M. W. Chase, from which it differs by the lateral sepals connate to ca $2 / 3$ of their length (vs lateral sepals connate into cymbiform, bifid lamina) and the form of the lip callus. In the new species the callus consists of a glabrous, cup-like thickening in the basal 1/7 of the lip, while in C. olivacea it is a keel-like process with a small obtuse lobe on each side and it extends to $c a 1 / 5$ of the lip length. 


\section{KeY to CAUCAEA SPECIES KNOWN FROM COLOMBIA AND ECUADOR}

1. Lip triangular-ovate in outline, up to $c a 5 \mathrm{~mm}$ long C. radiata (Lindl.) Mansf.

1* Lip distinctly 3-lobed, more than $10 \mathrm{~mm}$ long ... 2

2. Lip disc papillate in center..............

C. kennedyi (Stacy) N. H. Williams \& M. W. Chase

$2^{*}$. Lip disc not papillate . . . . . . . . . . . . . 3

3. Lateral sepals connate up to about the middle . . . 4

3. Lateral sepals connate almost to their apices (at least $2 / 3$ of their length) ............... 12

4. Base of lip middle lobe deeply cordate .......

..C. spathulata N. H. Williams \& M. W. Chase

4. Base of lip middle lobe not cordate ...... 5

5. Isthmus between lip lobes long, almost equaling lateral lobe length

C. pseudoandigena Szlach. \& Kolan.

5. Isthmus between lip lobes reduced . . . . . . 6

6. Lip base truncate to subcordate . . . . . . . 7

6. Lip base cuneate . . . . . . . . . . . . . 10

7. Lip middle lobe transversely elliptic to cordate-reni-

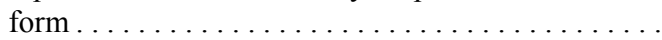

C. nubigena (Lindl.) N. H. Williams \& M. W. Chase

7* Lip middle lobe cuneate-flabellate . . . . . . . 8 8

8. Lip callus rectangular ................

C. tarquiensis (Stacy) N. H. Williams \& M. W. Chase

8. Lip callus composed of 3 ridges . . . . . . . . 9

9. Lip lateral lobes overlapping middle lobe ........

... C. macrotyle (Königer \& J. Portilla) Königer

9. Lip lateral lobes not overlapping middle lobe .....

C. alticola (Stacy) N. H. Williams \& M. W. Chase

10. Lip lateral lobes truncate $\ldots \ldots \ldots \ldots \ldots$

C. erosilabia (Stacy) N. H. Williams \& M. W. Chase 10. Lip lateral lobes rounded ........... 11

11. Lip about equally long and wide ............ C. tunguraguensis (Stacy) N. H. Williams \& M. W. Chase

11. Lip wider than long $\ldots \ldots \ldots \ldots \ldots \ldots \ldots$

C. chimborazoensis (Stacy) N. H. Williams \& M. W. Chase

12. Lip callus glabrous $\ldots \ldots \ldots \ldots \ldots \ldots 13$

$12^{*}$. Lip callus hairy in basal part . . . . . . 18

13. Lip isthmus reduced ............... 14

13. Lip isthmus conspicuous . . . . . . . . . . . . 15

14. Tepals dorsally papillate ..............

C. azuayensis (Kraenzl.) N. H. Williams \& M. W. Chase

14. Tepals glabrous . . . . . . . . . . . . . .

C. aequinoctialis (Stacy) N. H. Williams \& M. W.

Chase
15. Lip isthmus very long, $c a 1 / 4-1 / 3$ of total lip length $\ldots \ldots \ldots \ldots \ldots \ldots \ldots \ldots \ldots$

$15^{*}$. Lip isthmus short, less than $1 / 5$ of total lip length

16. Lip callus in form of 2 parallel ridges ...... C. pichinchae Szlach. \& Kolan.

16. Lip callus consisting of a broad ridge with a pair of small appendices in its apical part ........ ......... C. dodsoniana Szlach. \& Kolan.

17. Lip callus cup-like

............. C. duquei Szlach. \& Kolan.

$17^{*}$. Lip callus a single, short ridge . . . . . . . . .

............. C. caucana Szlach. \& Kolan.

18. Inflorescence erect ............. 19

18 . Inflorescence arcuate . . . . . . . . . . . 20

19. Lip callus short, $c a 1 / 5$ of lip length .........

C. olivacea (Kunth) N. H. Williams \& M. W. Chase

19. Lip callus long, $c a 1 / 3$ of lip length . . . . . . . .

C. cucullata (Lindl.) N. H. Williams \& M. W. Chase

20. Lip callus consisting of parallel ridges $\ldots 21$

$20 *$ Lip callus tuberculate . . . . . . . . . 24

21. Lip callus compressed .................

C. rhodosticta (Kraenzl.) N. H. Williams \& M. W. Chase

$21^{*}$. Lip callus not compressed . . . . . . . . 22

22. Callus middle ridge shorter than lateral ones. .

....................... 23

22. Callus middle ridge as long as lateral ones ...

C. tripterygia (Rchb. f.) N. H. Williams \& M. W. Chase

23. Callus concave

C. dayana (Rchb. f.) N. H. Williams \& M. W. Chase

23. Callus convex .......................

C. phalaenopsis (Lindl. \& Rchb. f.) N. H. Williams \& M. W. Chase

24. Lip lateral lobes subquadrate, reduced ....... C. mimetica (Stacy) N. H. Williams \& M. W. Chase

24. Lip lateral lobes semicircular, well-developed ...................... 25

25. Gynostemium slender, clinandrium short ...... C. andigena (Linden \& Rchb. f.) N. H. Williams \& M. W. Chase

25. Gynostemium stout, clinandrium high . . . . . . . C. sanguinolenta (Lindl.) N. H. Williams \& M. W. Chase

ACKNOWLEDGEMENTS. The Curator and staff of the Missouri Botanical Garden Herbarium are thanked for their kind hospitality and assistance during visits, and for making material available on loan. We are grateful to 
Natalia Olędrzyńska for preparing the illustrations, and the anonymous reviewers for their valuable comments on the manuscript. The research described here was supported by the Polish Ministry of Science and Higher Education (research grant no. 8124/B/PO1/2011/40) and by the Foundation for Polish Science (Fundacja na rzecz Nauki Polskiej, FNP).

\section{REFERENCES}

Dodson C. H. \& Luer C. A. 2005. Orchidaceae, Genera $A A$ - Cyrtidiorchis. In: G. Harling \& L. Andersson (eds), Flora of Ecuador 76: 1-347. Botanical Institute, Göteborg University, Riksmuseum, Stockholm.

KöNiger W. 2003. Neue Arten der Gattungen Cyrtochilum, Masdevallia und Oncidium. Arcula 14: 346-360.

Kraenzlin F. 1922. Orchidaceae-Monandrae, Tribus Oncidiinae - Odontoglosseae Pars II. Engelmann, Leipzig. Lindley J. \& Paxton J. 1850-1851. Paxton's Flower garden. 1. Bradbury and Evans, London.

Lindley J. 1855. Folia Orchidacea, an enumeration of the known species of Orchids 35: Oncidium. J. Matthews, London.
Lindley J. \& Paxton J. 1850-1851. Paxton's Flower garden. 1. Bradbury and Evans, London.

Neubig K. M., Whitten W. M., Williams N. H., Blanco M. A., Endara L., Burleigh J. G., Silvera K., Cushman J. C. \& Chase M. W. 2012. Generic recircumscriptions of Oncidiinae (Orchidaceae: Cymbidieae) based on maximum likelihood analysis of combined DNA datasets. Bot. J. Linn. Soc. 168: 117-146.

Ortiz Valdivieso P. \& Uribe Vélez C. 2007. Galería de Orquideas de Colombia (CD edition). Bogotá, Asociación Bogotana de Orquideología.

Stacy J. 1975. Studies in the genus Oncidium I (Section Cucullata). Bot. Mus. Leaft. 24: 133-191.

Swartz O. 1800. Orchidernes flaegter och arter upstaellde. Kongl. Vetensk. Acad. Nya Handl. 21: 202-254.

Szlachetko D. L. \& Mytnik-EjSmont J. 2009. Gynostemia Orchidalium IV. Acta Bot. Fenn. 180: 1-313.

Williams N. H., Chase M. W. \& Whitten W. M. 2001. Phylogenetic position of Miltoniopsis, Caucaea, a new genus, Cyrtochiloides, and relationship of Oncidium phymatochilum based on nuclear and chloroplast DNA sequence data (Orchidaceae: Oncidiinae). Lindleyana 16: 272-285.

Received 27 July 2015 